\title{
DETEKSI MUTASI GEN Emb SEBAGAI SIFAT RESISTENSI PRIMER FIRST LINE ORAL AGENTS ETHAMBUTOL PADA PASIEN TB PARU BTA + DI WILAYAH KERJA PUSKESMAS KABUPATEN LOMBOK TIMUR
}

\author{
Dewi Utary*, Fachrudi Hanafi**, Sugijati*** \\ Fakultas Kedokteran Universitas Islam Al-Azhar, Poltekkes Kemenkes Mataram \\ Email : dewisydney@unizar.ac.id
}

\begin{abstract}
ABSTRAK
Latar belakang : Ethambutol termasuk obat lini pertama pengobatan TB yang berkhasiat spesifik terhadap mikobakteri dan tidak terhadap bakteri-bakteri lain. Hasil penelitian pola kepekaan kuman M.tuberculosis terhadap OAT menggunakan teknik PCR dari sampel dahak dan cairan pleura penderita TB Paru di RSUD Provinsi NTB diperkirakan telah mengalami resistensi terhadap Ethambutol sebesar 29,4\%. Frekuensi dan jenis mutasi pada gen Emb juga spesifik karena perbedaan geografis sehingga sangat perlu dilakukan pemeriksaan sifat resistensi gen Emb pada setiap daerah. Tujuan penelitian : Mendeteksi adanya mutasi gen Emb Mycobacterium tuberculosis sebagai sifat resistensi primer first line oral agents Ethambutol pada penderita TB Paru dengan BTA + yang ada di wilayah kerja Puskesmas Kabupaten Lombok Timur. Penelitian ini bersifat observasional deskritif. Metode yang digunakan dalam mendeteksi adanya mutasi gen Emb adalah menggunakan teknik PCR dan dilanjutkan dengan nested PCR. Variabel penelitian adalah sputum penderita TB Paru baru dengan $\mathrm{BTA}+$ + Dari hasil pengumpulan data didapatkan sebanyak 50 sampel sputum $\mathrm{BTA}+$. Dari pemeriksaan dengan PCR diagnostik Tb1 dan Tb2, semua sampel dinyatakan $+(100 \%)$ mengandung $M$. tuberculosis. Setelah dilakukan pemeriksaan PCR kemudian dilanjutkan dengan analisis nested PCR dan hasilnya telah terbukti terjadi mutasi pada daerah komplementer primer yang merupakan target gen Emb M. tuberculosis dan didapatkan sebanyak 5 sampel (10\%) yang dinyatakan resisten atau terjadi mutasi sedangkan sisanya 45 sampel (90\%) masih sensitif atau tidak terjadi mutasi. Lima sampel tersebut berasal dari Puskesmas Wanasaba (2), Terara (1), Denggen (1) dan Lepak (1). Kesimpulan : Telah terjadi resistensi primer first line oral agents Ethambutol pada beberapa penderita TB Paru dengan BTA + di wilayah kerja Puskesmas Kabupaten Lombok Timur.
\end{abstract}

Kata kunci : resistensi primer, Ethambutol, TB Paru

Jurnal Kedokteran 


\section{PENDAHULUAN}

Resistensi terhadap obat anti tuberkulosis (OAT) ada 3 macam yaitu (1) mutan yang resisten, (2) resistensi sekunder/ resistensi yang diperoleh dan (3) resistensi primer. Resistensi terhadap OAT dapat timbul karena beberapa faktor antara lain pemberian terapi TB yang tidak adekuat akan menyebabkan mutan resisten. Hal ini amat ditakuti karena dapat terjadi resisten terhadap OAT lini pertama, masa infeksius yang terlalu panjang akibat keterlambatan diagnosis akan menyebabkan penyebaran galur resisten obat. Penyebaran ini tidak hanya pada pasien di rumah sakit tetapi juga pada petugas rumah sakit, asrama, penjara dan keluarga pasien, pasien dengan TB -MDR diterapi dengan OAT jangka pendek akan tidak sembuh dan akan menyebarkan kuman yang resisten, pasien dengan OAT yang resisten terhadap kuman Tuberkulosis yang mendapat pengobatan jangka pendek dengan monoterapi akan menyebabkan bertambah banyaknya OAT yang resisten dimana hal ini menyebabkan seleksi mutasi resisten karena penambahan obat yang tidak multipel dan tidak efektif (Priyanti, 2008; Crofton dkk, 2002).

Resistensi obat primer dan didapat bisa disebabkan karena pengobatan yang tidak adekuat, obatnya substandar, tidak sesuai atau "mono terapy" (terapi satu obat). Proses biologik alamiah menyebabkan daya tahan mikroba melakukan upaya resistensi yang dapat ditransmisikan secara genetik ketika diobati dengan suatu antimikroba atau penolakan (ekspulsi) fisik obat tersebut (Syaifudin, 2005).

Zhang menemukan bahwa gen Emb yang menyandi enzim transferase berkaitan langsung dengan sifat resistensi M.tuberculosis terhadap Ethambutol. Hasil penelitian Salim dkk (2010) yang melakukan penelitian pola kepekaan kuman $M$. tuberculosis terhadap OAT menggunakan teknik PCR dari sampel dahak dan cairan pleura penderita TB yang berobat di RSUD Provinsi NTB dari 17 isolat M.tuberculosis yang diperiksa didapatkan Ethambutol 29,4 \% telah mengalami resistensi. (Kosasih dkk,1989; Zhang et al, 1992; Salim,2010). 
Ethambutol termasuk obat lini pertama pengobatan TB yang berkhasiat spesifik terhadap mikobakteri dan tidak terhadap bakteri-bakteri lain. Kerja bakteriostatiknya mungkin berdasarkan penghambatan sintesis RNA (Tjay T.H, 2010). Ethambutol bekerja dengan cara menghambat arabinosyl transferase yang terlibat dalam biosintesis dinding sel (Takayama and Kilburn, 1989 cit. Rabia Johnson) .

Bukti - bukti genetik menunjukkan bahwa mutasi gen gen Emb, merupakan penyebab kekebalan Ethambutol, dengan persentase mutasi gen Emb sebesar $60 \%-70 \%$.

Data dari RS persahabatan tahun 1993 menunjukkan resistensi M. tuberculosis terhadap Ethambutol adalah $7,7 \%$, sedangkan penelitian di provinsi DKI, Sumatera Barat dan Sulawesi Selatan berkisar antara 11,9 $\%$ dan 15,6\%. Hasil penelitian Syaifudin (2005) menemukan dari 70 sampel yang diuji sifat resistensi Ethambutol berdasarkan mutasi gen Emb dengan menggunakan metode SSCP radioaktif didapatkan $7,1 \%$

Jurnal Kedokteran

Vol. 06 No. 01 Desember 2020 telah mengalami mutasi pada gen Emb nya atau bersifat resisten.

Walaupun di Indonesia beberapa laporan penelitian resistensi M. tuberculosis telah dilakukan dengan persentase kasus yang berbeda setiap daerah. Perbedaan angka rersistensi ini disebabkan karena sifat fenotipe dan genotipe dari Mycobacterium tuberculosis secara geografis yang berbeda. Frekuensi dan jenis mutasi pada gen Emb juga spesifik karena perbedaan geografis sehingga sangat perlu dilakukan pemeriksaan sifat resistensi gen Emb pada setiap daerah, terutama kasus suspek dan BTA (+) nya besar (Syaifudin dkk, 2005).

Manfaat dari peneltian ini adalah didapatkan informasi mengenai pola resistensi dan pemetaan daerah yang telah mengalami resistensi primer pada first - line oral agents Ethambutol yang disebabkan karena terjadinya mutasi atau perubahan susunan nukleotida gen Emb $M$. tuberculosis pada penderita TB paru baru di wilayah Kabupaten Lombok Timur sehingga dapat membantu program pemberantasan dan pengendalian 
infeksi Tuberkulosis dalam mengambil tindakan yang lebih cepat dan intensif.

Tujuan penelitian ini adalah mendeteksi adanya mutasi gen Emb M. tuberculosis sebagai sifat resistensi primer first line oral agents Ethambutol pada penderita TB paru dengan BTA + yang ada di wilayah kerja Puskesmas Kabupaten Lombok Timur

\section{METODE PENELITIAN}

Penelitian ini merupakan penelitian observasional deskriptif yaitu mendeteksi adanya mutasi gen Emb M. tuberculosis terhadap resistensi primer first - line oral agents Ethambutol pada penderita TB paru BTA (+).

Tempat penelitian dilakukan di wilayah kerja puskesmas kabupaten Lombok timur. Pengambilan sampel sputum penderita TB Paru baru dengan BTA (+) dan dilanjutkan dengan pemeriksaan biologi molekuler PCR dilakukan di Laboratorium Molekuler Instalasi Litbang-tekkes Unit Riset Biomedik RSUD Provinsi NTB. Sampel penelitian penderita TB Paru baru dengan BTA (+) yang ada di wilayah kerja puskesmas kabupaten Lombok Timur. Pengambilan sampel menggunakan teknik non random accidental sampling yaitu penderita TB Paru baru yang kebetulan datang memeriksakan diri ke Puskesmas dengan hasil pemeriksaan mikroskopis sputum BTA (+) dan belum mendapat pengobatan program.

Data yang diperoleh dianalisis secara deskriptif dengan kriteria jika sampel PCR positif (+) dengan primer diagnostik Tb1-2 tetapi negatif (-) dengan primer Emb1-2 atau positif (+) dengan primer gen Emb1 tetapi negatif (-) dengan primer gen Emb2, maka isolat $M$. tuberculosis pada sampel sputum penderita TB tersebut mengalami mutasi pada daerah komplementer primer atau urutan basa tidak cocok/nucleotida mismatch dari target gen Emb nya, sehingga bersifat resisten terhadap masing masing primer yang bersangkutan (Salim, 2010).

\section{HASIL DAN PEMBAHASAN}

\section{Hasil Penelitian}

Penderita TB paru yang diambil sebagai sampel dalam 
penelitian ini adalah penderita $\mathrm{TB}$ Paru baru dengan sputum BTA + dan belum pernah mendapatkan pengobatan program dari Puskesmas. Pada penelitian ini berhasil dikumpulkan 50 sputum BTA selama masa pengumpulan data.

Sebaran $\begin{gathered}\text { sampel yang } \\ \text { didapatkan berdasarkan }\end{gathered}$
kenis
sebanyak 32 orang $(64 \%)$ dan
perempuan 18 orang $(36 \%)$, yang
berasal dari 16 Puskesmas dari 29
Puskesmas yang ada di wilayah
Kabupaten Lombok Timur.

Tabel 1. Sebaran jumlah sampel berdasarkan kelompok umur

\begin{tabular}{cc}
\hline $\begin{array}{c}\text { Kelompok } \\
\text { Umur }\end{array}$ & Jumlah sampel \\
\hline $20-30$ tahun & 22 \\
\hline $31-40$ tahun & 11 \\
\hline $41-50$ tahun & 9 \\
\hline $51-60$ tahun & 5 \\
\hline$>60$ tahun & 3 \\
\hline
\end{tabular}

Pada table 1. dapat dilihat sebaran sampel berdasarkan kelompok umur, adalah kelompok umur 20 - 30 tahun sebanyak 22 orang, 31-40 tahun sebanyak 11 orang, 41-50 tahun sebanyak 9 orang, 51-60 orang sebanyak 5 orang

Jurnal Kedokteran

Vol. 06 No. 01 Desember 2020 dan > dari 60 tahun sebanyak 3 orang.

Jumlah Puskesmas yang digunakan sebagai tempat sampel dalam penelitian ini sebanyak 16 Puskesmas dengan sebaran jumlah sampel masing-masing Puskesmas dapat dilihat pada tabel 2 .

Tabel 2. Sebaran Jumlah Sampel berdasarkan Asal Puskesmas

\begin{tabular}{lc}
\hline Asal Puskesmas & Jumlah sampel \\
\hline Jerowaru & 1 \\
\hline Selong & 6 \\
\hline Keruak & 2 \\
\hline Terara & 3 \\
\hline Masbagik & 12 \\
\hline Wanasaba & 5 \\
\hline Labuan Lombok & 5 \\
\hline Denggen & 4 \\
\hline Aikmel & 2 \\
\hline Dasan Lekong & 2 \\
\hline Sakra & 2 \\
\hline Kerongkong & 2 \\
\hline Lepak & 1 \\
\hline Lendang & 1 \\
Nangka & 1 \\
\hline Korleko & 1 \\
\hline Rensing & \\
\hline
\end{tabular}


Berdasarkan hasil dari tabel di atas menunjukkan jumlah sampel yang terbanyak adalah Puskesmas Masbagik sebesar 12 sampel, sedangkan jumlah sampel yang paling sedikit (1 sampel) adalah Puskesmas Lepak, Lendang Nangka, Korleko dan Rensing.

\section{Hasil pemeriksaan PCR-Tb diagnostik dari sampel sputum penderita TB Paru}

Sampel sputum sebanyak 50 diekstraksi dengan menggunakan metode DNAzol, dilakukan PCR diagnostik dengan menggunakan pasangan primer $\mathrm{Tb} 1$ dan $\mathrm{Tb} 2$ (primer untuk diagnostik). PCR ini digunakan untuk mendeteksi DNA Mycobacterium tuberculosis.

Hasil analisis PCR-Tb menggunakan primer $\mathrm{Tb} 1 \mathrm{dan} \mathrm{Tb} 2$ pada 50 sampel sputum dari penderita TB Paru BTA (+) diperoleh semua sampel (100\%) positif (+). Hasil ini membuktikan bahwa semua sampel sputum tersebut terdapat DNA Mycobacterium tuberculosis. Hasil analisis PCR ini mempertegas hasil pemeriksaan mikroskopis BTA yang

Jurnal Kedokteran

Vol. 06 No. 01 Desember 2020 menyatakan ke 50 sampel sputum tersebut positif $(+)$.

\section{Hasil pemeriksaan PCR gen Emb}

M. tuberculosis dengan metode Nested PCR

Metode nested PCR dilakukan untuk mempelajari dan mengetahui adanya mutasi gen Emb M. tuberculosis terhadap resistensi primer first - line oral agents Ethambutol pada penderita TB paru BTA (+). Semua 50 sampel yang positif pada pemeriksaan PCR tahap I / pemeriksan TB diagnostik selanjutnya dilakukan pemeriksaan dengan metode nested PCR. Pemeriksaan ini dilakukan dalam dua tahap dengan menggunakan 2 pasangan primer gen Emb.

Hasil analisis PCR menggunakan metode nested PCR untuk mengetahui terjadinya mutasi pada daerah komplementer primer yang merupakan target gen Emb $M$. tuberculosis. Dari hasil tersebut terdapat 5 sampel (10\%) yang dinyatakan resisten atau telah terjadi mutasi dan 45 sampel (90\%) yang dinyatakan masih sensitif atau tidak terjadi mutasi. Lima (5) sampel yang terdeteksi terjadinya mutasi pada daerah komplementer primer karena 
ketidakcocokan urutan basa atau terjadinya nucleotide mismatch adalah berasal dari wilayah kerja Puskesmas Wanasaba sebanyak 2 sampel sedangkan dari Puskesmas Terare, Denggen dan Lepak masing - masing sebanyak 1 sampel. Hasil ini membuktikan bahwa telah terjadi resistensi primer terhadap first line oral agents Ethambutol di wilayah kerja Puskesmas Kabupaten Lombok Timur.

\section{Pembahasan}

Deteksi yang cepat untuk mengetahui resistensi obat dari $M$. tuberculosis sangat diperlukan untuk pilihan terapi Tuberkulosis. Ethambutol merupakan salah satu obat anti TB yang utama selain Rifampisin dan Isoniazid. Ethambutol adalah derivat etilendiamin yang berkhasiat spesifik terhadap Mycobacteri dan tidak terhadap bakteri-bakteri lain. Ethambutol bersifat bakteriostatik yang menginhibisi sintesa mikolat pada dinding sel $M$. tuberculosis. Obat didistribusikan dengan luas dan melewati blood brain barrier. Enzim utama yang mengkatalisasi metabolismenya adalah arabinosyl transferase yang mempunyai ekspresi yang variabel, menyebabkan variasi yang luas pada masa paruhnya. Obat ini diindikasikan untuk semua bentuk Tuberkulosis dengan kuman yang sensitif baik untuk pencegahan maupun pengobatan (Stella, 2008).

Target kerja Ethambutol sebagai anti tuberculosis adalah dengan menghambat enzim arabinosyl transferase, yang diperlukan dalam biosintesa asam mikolat dinding sel Mycobacterium tuberculosis. Gen Emb adalah satusatunya gen yang dapat mengaktifkan Ethambutol, dengan demikian mutasi gen Emb strain $M$. tuberculosis menyebabkan $M$. tuberculosis menjadi resisten terhadap Ethambutol (Hillaludin, 2009).

Studi analisis molekuler menunjukkan bahwa mutasi pada kodon 306 pada daerah Emb merupakan $70 \%$ dari kelompok $M$. tuberculosis resistensi obat Ethambutol (Salim dkk, 2010).

Resistensi primer adalah keadaan resistensi terhadap Obat Anti Tuberkulosis (OAT) pada penderita yang belum pernah 
mendapat pengobatan dengan OAT sebelumnya. Faktor risiko terjadinya resistensi primer OAT adalah kasus infeksi oleh $M$. tuberculosis yang resistensi OAT. Keadaan resistensi primer ini dijumpai secara geografis pada tempat yang mempunyai risiko tinggi untuk resistensi OAT. Resistensi OAT disebabkan oleh mutasi kromosomal terhadap masing - masing OAT. Pengaruh terhadap derajat mutasi dalam kasus klinis terletak pada proporsi kuman yang resisten dan perkembangbiakan kuman yang resisten. Proses resistensi ini dimulai dengan mutasi genetik, diikuti perkembangbiakan populasi yang resisten, kemudian menimbulkan bakteri yang menjadi resisten terhadap OAT (Paul, 1999).

Pada penelitian ini digunakan beberapa pasangan primer yang daerah komplementernya merupakan posisi yang diketahui mengalami mutasi dan berhubungan dengan sifat resistensi obat.

Hasil penelitian dengan menggunakan metode nested PCR pada target mutasi gen Emb $M$. tuberculosis membuktikan bahwa telah terdapat resistensi primer $M$. tuberculosis terhadap obat
Ethambutol di wilayah kerja Puskesmas Kabupaten Lombok Timur. Hasilnya terdapat sebanyak 5 sampel (10\%) yang dinyatakan resisten atau terjadi mutasi pada gen Emb dan 45 (90\%) dinyatakan sensitif atau tidak terjadi mutasi. Lima (5) sampel yang dinyatakan resisten tersebut berasal dari wilayah kerja Puskesmas Wanasaba (2 sampel), Puskemas Terara, Denggen dan Lepak masing - masing 1 sampel. Semua sampel yang terdeteksi terjadinya mutasi pada daerah komplementer primer dianggap sebagai akibat ketidak cocokan urutan basa atau terjadinya nucleotide mismatch. Hasil penelitian ini menambah data tentang kejadian resistensi primer $M$. tuberculosis.

Timbulnya resistensi terhadap Obat Anti Tuberkulosis di Mataram NTB telah dilaporkan oleh Salim, dkk (2010) yang membuktikan telah terjadi resistensi terhadap OAT pada sampel cairan pleura dari pasien dengan diagnosis TB Paru berdasarkan hasil pemeriksaan Radiologi. Hasilnya didapat dari 17 isolat Mycobacterium tuberculosis yang diperiksa dengan teknik PCR 
didapatkan $29,4 \%$ mengalami resisten terhadap Ethambutol.

Pada simposium resistensi antimikroba di Indonesia, Parwati, dkk dalam penelitiannya di Jawa Barat menyatakan bahwa pada kasus Tuberkulosis baru ( $\mathrm{n}=644)$ sebanyak 50 pasien resisten terhadap Isoniazid, 43 pasien (67\%) resisten Rifampisin, 28 pasien $(4,3 \%)$ resisten terhadap Ethambutol, 44 pasien $(6,8 \%)$ resisten terhadap Streptomisin dan 24 orang $(3,7 \%)$ mengalami Multi Drug Resistant Tuberculosis / MDR TB (Stella,2008).

\section{KESIMPULAN}

1. Sampel sputum dari penderita TB Paru BTA (+) di wilayah kerja Puskesmas Kabupaten Lombok didapatkan sebanyak 50 sampel dan semuanya (100\%) dinyatakan positif dengan menggunakan pemeriksaan PCR diagnostik Tb1 dan Tb2.

2. Analisis nested PCR membuktikan terjadinya mutasi pada daerah komplementer primer yang merupakan target gen Emb Mycobacterium tuberculosis dan ditemukan sebanyak 5 sampel (10\%) yang dinyatakan resisten atau terjadi mutasi dan 45 (90\%) dinyatakan sensitif atau tidak terjadi mutasi. Hasil ini membuktikan telah terjadi resistensi primer first - line oral agents Ethambutol pada penderita TB Paru BTA(+)

\section{SARAN}

1. Pada penelitian ini adalah tidak dilakukan cross check secara klinis dan pemeriksaan sputum BTA pasca pengobatan 6 bulan pada penderita yang telah terbukti mengalami resistensi primer, sehingga tidak dapat dikonfirmasi hasil keberhasilan terapi dan keadaan klinisnya setelah mendapatkan terapi OAT. Oleh karena itu hasil ini perlu dilakukan cross check secara klinis dan pemeriksaan sputum BTA pasca pengobatan 6 bulan pada penderita.

2. Sangat perlu dilakukan pelaporan apapun yang didapat dari hasil pemeriksaan mikroskopis setelah selesai pengobatan terapi OAT, walaupun bentuk basil Mycobacterium tuberculosisnya sudah berbentuk fragmented. 
3. Perlu dilakukan penelitian lanjutan untuk menentukan ada tidaknya mutasi pada satu basa dengan menggunakan metode sequensing DNA atau HDF (Heteroduplex Formation).

\section{DAFTAR PUSTAKA}

Aditama,T,Y.; Chairil A.S., dan Herry B.W,1995. Resistensi primer dan sekunder Mycobacterium tuberculosis. Cermin dunia kedokteran. Jakarta

Arlina, G, 2003. Kekerapan Tuberculosis Paru Pada Pasangan Suami - Istri Penderita Tuberculosis Paru yang Berobat di Bagian Paru RSUP. H. Adam Malik USU Sumatera Utara

Boekitwetan, P. 1999. Resistensi Multiple Obat Anti Tuberkulosis. Bagian Mikrobiologi Fakultas Kedokteran Universitas Trisakti. Jakarta

Crofton, S.J.; Horne, N; Miller, F, 2002. Tuberkulosis Klinis, Widya Medika, Jakarta

Dikes Lotim, 2010. Profil Bidang P2PL Tahun 2010

Hilaluddin, 2008. Multi-Drug Resistensi (MDR) Pada Penderita Tuberculosis Paru Dengan Diabetes Melitus, Laporan Program Pendidikan Dokter Spesialis I Paru

Kosasih, O; Soemantri E.S; dan Soewarno W, 1989. Resistensi Kuman Tuberculosis terhadap Beberapa Jenis Obat Anti Tuberculosis. Medika.
Muhammad Asa ad Maidin, 2005. Harapan dan Tantangan Aplikasi Reaksi Rantai Polimerase (PCR) Multipleks dalam Pemberantasan TB Paru di Indonesia (Suatu Pendekatan Biologi Molekuler). Suplement vol 26

Riskesdas, 2010. Badan Penelitian dan Pengembangan Kesehatan Kementerian Kesehatan R.I. Jakarta 2010 Soedarsono, 2010. Tuberkulosis Multidrug-Resistent. Deteksi dan Penatalaksanaanya. Workshop dan Seminar Penatalaksanaan Terkini Berbagai Penyakit Metabolik, Kardiovaskuler dan Paru. Mataram

Soepand, P.Z. 2008. Diagnosis dan Faktor Yang Mempengaruhi Terjadinya TB-MDR. Departemen Pulmonologi dan Ilmu Kedokteran Respirasi FKUI-RS

Persahabatan.Jakarta

Sugiyono, 2005. Statistika dan Penelitian, Penerbit Alfabeta Bandung

Stella I, 2003. Tinjauan Kepustakaan Tuberculosis Paru. FK UI. Jakarta

Syaifudin, M; Rosilawati, M; Irawa, H; Bela, B. 2005. Identifikasi Mycobacterium Tuberclosis dan Analisa Mutasi Gen rpoB dan katG Penyebab Resistensi Ganda dengan Teknik Molekuler

Thalib, S; Widita, H; Muttaqin, Z. 2010. Penelitian Pola Kepekan Kuman Mycobacterium Tuberculosis Terhadap Obat Anti - TB Menggunakan Teknik PCR. Jurnal Kedokteran Mataram, Nomor 6 Juni 2010 
WHO, 2008. Global Tuberculosis Control. Geneva

Zhang, Y, Heym B, Allen B, Young $\mathrm{D}$ and Cole S, 1992. The CatalasePeroxidase Gene and Isoniazide

Resistance of Mycobacterium

Tuberculosis. Nature 